\title{
Monthly endoscopy surveillance culture facilitates detection of breaches in the scope reprocessing procedure: 5 year-experience in an endoscopy center
}

\author{
Hsu-Heng Yen ( 91646@cch.org.tw ) \\ Changhua Christian Hospital
}

Shu-Hui Chen

Changhua Christian Hospital

Huei-Wen Lai

Changhua Christian Medical Foundation Changhua Christian Hospitalpital

Hui-Lan Chang

Changhua Christian Hospital

\section{Yu-Chun Hsu}

Changhus Christian Hospital

\section{Fu-Yuan Siao}

Changhua Christian Medical Foundation Changhua Christian Hospital

\section{Research article}

Keywords: endoscopy surveillance culture, scope reprocessing procedure, endoscope contamination

Posted Date: December 20th, 2019

DOI: https://doi.org/10.21203/rs.2.19420/v1

License: (c) (i) This work is licensed under a Creative Commons Attribution 4.0 International License.

Read Full License 


\section{Abstract}

AIM To review the clinical impact of monthly microbiology surveillance culture for monitoring endoscope contamination after high-level disinfection.

METHODS Monthly surveillance culture of the endoscopes was conducted from January 2014 to December 2018 at our endoscopy center. A total of 1931 cultures were collected, including 765 cultures from 16 gastroscopes, 730 cultures from 18 colonoscopes, 379 cultures from 8 duodenalscopes, 46 cultures from 1 echoscopes, and 11 cultures from 1 enterscope. Cultures were obtained from ready-to-use endoscopes after a full reprocessing cycle and storage. Samples were cultured to test for aerobic and anaerobic bacteria.

RESULTS The positive culture rates for the endoscope were $2 \%$ (15/765) for gastroscopes, $1.9 \%(14 / 730)$ for colonoscopes, $0.8 \%$ (3/379) for duodenscopes, $4.3 \%$ (2/46) for echoscopes, and $9.1 \%(1 / 11)$ for enterscopes. These findings were predominantly attributed to human factors $(71.4 \%, 25 / 35)$ followed by storage cabinet failure $(14.3 \%, 5 / 35)$, automatic endoscope reprocessing failure $(11.4 \%, 4 / 35)$, and endoscope channel damage $(2.8 \%, 1 / 35)$. Multivariate analysis showed that the years 2015 [odds ratio (OR) $0.19,0.04$ to 0.91 ], 2016 (OR $0.21,0.05$ to 0.80 ), and 2017 (OR $0.22,0.06$ to 0.83 ) were associated with decreased risk of endoscope contamination. The age, type, and number of times the scope was used were not related to contamination.

CONCLUSIONS A low risk of endoscope contamination was found over a 5-year period in our endoscopy center. The most common cause of contamination was human factor. Duodenalscopes showed the lowest scope contamination rate. We suggested the implantation of a systematic endoscope culture regardless of the type of scope to facilitate early detection of breaches in the scope reprocessing procedure in clinical practice.

\section{Introduction}

Modern endoscopes have delicate designs with long channels, valves, or elevators that are difficult to clean and are prone to damage. Endoscope reprocessing is a complex process that decontaminates endoscopes for subsequent reuse [1-3]. Failure of reprocessing can result in the transmission of pathogens. Endoscopy-associated infection has become an important issue since the outbreak of carbapenem-resistant Enterobacteriaceae (CRE) infection after endoscopic retrograde cholangiopancreatography in the USA between 2012 and 2015 [4]. These outbreaks resulted in efforts to investigate the quality and efficacy of endoscope reprocessing, as well as factors that influence transmission between endoscopes and patients $[2,5,6]$.

Microbiological surveillance is a method used to evaluate the outcome of endoscopy reprocessing and is used for regular quality control in endoscopy units $[1,7]$. Rigorous culturing of all duodenoscopes after reprocessing of every instrument was reported to terminate an ongoing outbreak of transmission related to duodenoscopes [8]. In the so-called culture and quarantine approach, all instruments are sampled after 
reprocessing then stored for $48 \mathrm{~h}$, pending the return of culture results verifying the absence of pathogenic organisms, before reuse [8]. Although this approach is ideal, it is not practical in busy daily practice and is expensive. The frequency of obtaining microbiology cultures varies from different international guidelines. The European Society of Gastrointestinal Endoscopy (ESGE) and European Society of Gastroenterology and Endoscopy Nurses and Associates guidelines recommend routine testing at intervals of no longer than 3 months [7]. The Australia guideline recommends that duodenoscopes and endoscopic ultrasound instruments are monitored every month, and other endoscopes are monitored every 3 months [9]. In the USA, microbiology testing of endoscopes after reprocessing, during storage, or before use is not advised [2]. The Digestive Endoscopy Society of Taiwan (DEST) recommends randomly testing at routine intervals [10].Surveillance culturing as a quality assurance measure is advised in these reprocessing guidelines but the optimal interval of surveillance remains controversial. In 2014, our institution began a monthly microbiology surveillance program for all endoscopy in use as a quality indicator due to lack of a reliable real-time indicator after endoscopy reprocessing. The present study reviewed the results of intensive microbiology surveillance, identifying risk factors related to scope contamination and its clinical impact on daily practice.

\section{Materials And Methods}

\section{Endoscope reprocessing cycles and storage}

The ESGE and DEST guidelines recommend that endoscope reprocessing cycle consists of bedside precleaning, manual leak testing, manual cleaning in the cleaning facility, and high-level disinfection in the automatic endoscope reprocessing (AER) $[1,10,11]$. Endoscopes were cleaned manually by qualified endoscopy technicians by brushing and rinsing with tap water and an enzymatic detergent. Manual cleaning was followed by decontamination by the technician using an AER (DSD EDGE Dual Basin AER, Medivators Inc., Minnesota, USA). The liquid disinfectant used was $0.55 \%$ ortho-phthalaldehyde solution, which was stored at $15{ }^{\circ} \mathrm{C}$ to $30^{\circ} \mathrm{C}$ and tested using a test strip prior to each use to ensure the concentration was above the minimum effective concentration. Following AER reprocessing and drying, the scope was transported or stored in a temperature-controlled cabinet for clinical use. The endoscopy unit have a standard protocol for reprocessing and education for the staff. The study didn't involve human material and the study was approved by the Institutional Research Board of the Changhua Christian Hospital (No. Y-108-0188).

\section{Endoscope sampling and culture methods}

In 2014, we began monthly sampling of the endoscope after high-level disinfection performed by two senior endoscopy technicians. Rinse samples were obtained by flushing the biopsy channels with $100 \mathrm{~mL}$ of sterile distilled water under highly aseptic conditions, distributing $50 \mathrm{~mL}$ into the working channel and $50 \mathrm{~mL}$ into the air/water channel. The distilled water was contained in an aseptic vial ( $20 \mathrm{~mL} / \mathrm{vial})$ manufactured for medical use. The total sample $(100 \mathrm{~mL})$ was recovered at the distal end of the endoscope and incubated at $30^{\circ} \mathrm{C}$ on plate count agar after filtration of $100 \mathrm{~mL}$ through a $0.45 \mu \mathrm{m}$ filter 
(Biosart100 Monitors 16401-47-06-ACK, Sartorius, Germany). The filter membrane obtained was aseptically removed, transferred to the total count broth (Biosart100 Nutrient Media 16400-02-TC-K, Sartorius, Germany), and incubated at $35^{\circ} \mathrm{C} \pm 1{ }^{\circ} \mathrm{C}$ for $48 \pm 3 \mathrm{~h}$. After incubation, results were expressed as the number of colony-forming units per $100 \mathrm{~mL}$. After culturing was complete, the endoscope was reprocessed and returned for reuse, pending negative culture results. Each endoscope was tested by culture once monthly, and the schedule for culturing was based on a scheduled volume and was preferentially performed at a weekend as the endoscope would be out of circulation for approximately $48 \mathrm{~h}$.

\section{Microbiology review process of the endoscopy units}

Positive cultures from the endoscope were followed up by a discussion with the infection control unit, followed by investigation into the source of contamination by the endoscopy center. The infection control unit identified and followed patients who underwent procedures using the contaminated device, reviewed the reprocessing process with staff, repeated the reprocessing of the endoscope, and only returned the endoscope to clinical use only after a repeat culture was found to be negative. In cases of persistent contamination, the scope was sent for ethylene oxide gas sterilization followed by a repeated reviewing process. The scope was sent to the manufacturer if permanent contamination occurred $[2,12]$.

\section{Statistical Analysis}

The extracted data were presented in Microsoft Excel software and analyzed using MedCalc Statistical Software version 18.11 (MedCalc Software bvba, Ostend, Belgium; https://www.medcalc.org; 2018). Chisquare test or Fisher's exact test was used for categorical variables. Statistical significance was considered for values of $\mathrm{P}<0.05$.

\section{Results}

\section{Microbiology surveillance results}

From January 2014 to December 2018, a total of 1931cultures, including 765 cultures from 16 gastroscopes, 730 cultures from 18 colonoscopes, 379 cultures from 8 duodenalscopes, 46 cultures from 1 echoscopes, and 11 cultures from 1 enterscope (Fig 1 ). The type, age, and monthly use of the scopes are summarized in Table 1. The overall positive culture rate was 1.8\% (35/1931), with three positive culture results considered to be insignificant ( $<10$ colonies of skin flora). The positive culture rates of the endoscopes were $2 \%$ (15/765) for gastroscopes, $1.9 \%$ (14/730) for colonoscopes, $0.8 \%$ (3/379) for duodenscopes, 4.3\% (2/46) for echoscopes, and 9.1\% (1/11) for enterscopes. The most frequently cultured pathogenic organism was Klebsiella pneumoniae $(\mathrm{n}=13)$ followed by Pseudomonas aeruginosa $(\mathrm{n}=11)$, Enterococcus spp. $(\mathrm{n}=1)$, Candida spp. $(\mathrm{n}=5)$, Alcaligenes faecalis $(\mathrm{n}=1)$, and Acinetobacter baumannii $(\mathrm{n}=1)$.

Analysis of the year of microbiology sampling revealed a higher rate (3.9\%) of scope contamination in 2018 (Table 2). There was no association between the age and type of scope and scope contamination 
rate (Tables 3 and 4). Multivariate analysis showed that the years 2015 [odds ratio (OR) $0.19,0.04$ to 0.91), 2016 (OR 0.21, 0.05 to 0.80), and 2017 (OR 0.22, 0.06 to 0.83) were associated with a decreased risk of endoscope contamination. The age, type, and monthly use of the scopes were not related to endoscope contamination.

\section{Risk factors for scope contamination}

A monthly meeting was held between the infection control center and endoscopy center for root cause analysis to investigate the cause of scope contamination (Table 5). The most common causes were found to be human factors $(71.4 \% ; 25 / 35)$, followed by storage cabinet damage $(14.3 \% ; 5 / 35)$, AER failure $(11.4 \% ; 4 / 35)$, and endoscope channel damage $(2.8 \% ; 1 / 35)$. In 2018 , there were five incidents of Candida spp. contamination in the same month. An investigation found that all the contaminated scopes were placed in the same endoscope storage cabinet and the cabinet drying function was found to be damaged. There were four incidents of scope contamination, and a review of the reprocessing procedure identified damage to the AER endoscope connector. There was one incident of persistent scope contamination, despite repeated culturing and ethylene oxide gas sterilization. The scope was finally sent to the manufacturer, and damage to the internal channel was found. The contamination was resolved by changing the channel of the scope.

\section{Discussion}

The present study reviewed a 5-year monthly microbiology endoscopy surveillance and found a low risk of endoscope contamination in our endoscopy unit. Consistent with previous reports, the most common cause of scope contamination was found to be human factors $[1,5,13,14]$. Despite the complex design of the duodenal scope and recent concerns about duodenal scope contamination $[3,5,15,16]$, duodenal scopes showed a lower scope contamination rate in our study compared with those in previous reports [7, $17,18]$ and the frequency of microbiology surveillance should be the same regardless the type of endoscope. A monthly culture of all endoscopes in our unit helped to detect scope contamination and pinpoint the step in the endoscope reprocessing procedure in which contamination occurred.

There are two main methods used to evaluate endoscope contamination after high-level disinfection: non-culture and culture-based methods. The former includes the use of ATP and bioburden testing for point-of-care testing for contamination to measure the performance of manual cleaning $[4,19,20]$. However, this method shows a poor correlation with cultures of fully reprocessed devices [4] and requires extra work, particularly in a high-volume unit. The microbiological culture of endoscopes is critical to understanding the efficacy of reprocessing and transmission of microorganisms during outbreak investigations $[8,17,18,21-23]$. However, the existing guidelines are inconsistent in terms of the recommended frequency and method of microbiological monitoring [7, 9, 24] (Table 6). In Europe [7] and Australia $[9,10]$, endoscopy microbiology surveillance is regarded as a critical indicator of endoscope reprocessing quality. DEST recommend that microbiology surveillance is performed at a regular 
frequency [10]. In contrast, the US guidelines recommend against the use of endoscopy microbiology and require more data before a surveillance program should be implemented by healthcare facilities [2]. In the present study, a low risk of scope contamination from various etiologies was identified in the monthly endoscopy surveillance program. Although scope contamination may not be correlated with patient infection, we found this strategy helped early identification of the breach of the reprocessing process before the occurrence of outbreak of scope-related infection.

Many studies have reported a higher rate of duodenal scope contamination $[7,17,18,25]$, and the ESGE recommends a close surveillance interval for duodenal scope compared with that for other types of scopes $[1,7]$. Because of increased awareness of the high risk of duodenal scope reprocessing failure and the report of duodenal scope transmitted infection in 2014, our endoscopy staff were trained and audited for duodenal scope reprocessing [20]. The rate of inadequate manual cleaning decreased from $70.4 \%$ to $18.8 \%$ after auditing the reprocessing process [20]. The present study found a low rate of duodenal scope contamination compared with that of other types of scopes. This may be due to an increased awareness of reprocessing of this specific type of scope within the unit. As prompt identification of contaminated endoscopes is vital to prevent an outbreak of scope transmission, we suggest that monthly microbiology surveillance program should be performed, regardless of the type of endoscope, especially in this era of overemphasizing duodenal scope contamination.

The present study found that human error was the most common cause of scope contamination [26, 27]. Despite established processing guidelines, high rates of non-compliance to the reprocessing process remain $[13,28]$. A lack of regular evaluation of reprocessing staff competence $(60 \%)$ and regular microbiological inspection $(56 \%)[29,30]$ in the endoscopy unit was previously shown to result in guideline non-compliance. Education of endoscopy staff was shown to decrease the rate of endoscope contamination after high-level disinfection $[19,27]$. In our unit, we performed an annual competence evaluation of endoscopy staff and still failed to eliminate non-adherence to the reprocessing guidelines. In 2018, our unit introduced the Olympus 290 system, which has a different design than the previously used Olympus 260 system. Thus, in 2018, a lack of familiarity with the new system and a mixture of different endoscope modes (Olympus 260 model and Olympus 2290 model ) were attributed to the increased incidence of human error in our endoscopy unit. This obvious challenge in the current endoscopy reprocessing procedures [30-32] was not addressed in the recent endoscopy reprocessing guidelines $[1,2]$. A wide variety of devices continually require reprocessing in the endoscopy unit, and technicians need to identify each type, brand, and model of endoscope and apply appropriate reprocessing procedure. Furthermore, complete reprocessing of each endoscope takes up to $40 \mathrm{~min}$ [33], and the technician may speed up the process due to high-volume loads, which may lead to an increased reprocessing error [26,34]. Memory violation due to too many reprocessing steps, a lack of real-time feedback, and visibility violation were the most causes of human errors during endoscopy reprocessing $[32,35,36]$. Therefore, future studies into endoscopy reprocessing are required to identify the optimal workload for endoscopy technicians, improve the design of endoscopes to simplify and unify the reprocessing procedures, and improve the reprocessing environment to make a safer, more efficient, and more compatible workspace [32]. 
The present study has some limitations. Quality control is fundamental to the delivery of safe and efficient endoscopic procedures, and surveillance cultures are an important method; however, the optimal method for sampling and culture incubation periods vary among different countries [37]. We adopted the flush method for microbiology surveillance, as recommended by the DEST guidelines, and the culture recovery rate may be lower than using the flush-brush-flush methods [22, 37]. Furthermore, we did not perform cultures for slow-growing agents such as Mycobacterium. Low scope contamination was found in our study compared with that in previous reports of $12.9 \%$ to $71.4 \%[17,18,23,25]$, although this may be an underestimation due to the culturing methods used and an incubation period of only $48 \mathrm{~h}$. Since there were no outbreaks of endoscope-related transmission such as CRE infection at our institution, we are not able to evaluate the impact of monthly culturing to prevent scope-related transmission. As culturenegative endoscopes may have clinically significant biological residues, monthly culture monitoring should not replace other infection control methods in the unit. Culturing methods can help to detect flaws in the reprocessing procedure that could increase the risk of transmission of infectious agents in the unit.

\section{Conclusions}

A low risk of endoscope contamination was found over a 5 year period in our endoscopy center. Human factors were found to be the leading cause of scope contamination. We suggest the implementation of a systematic endoscope culture regardless of the type of scope for the early detection and etiology of scope contamination in daily practice.

\section{Declarations}

\section{Acknowledgments}

The authors would like to thank Enago (www.enago.tw) for their English language review.

\section{Disclosure of interest}

The authors report no conflicts of interest.

\section{Ethic Statement}

The study didn't involve human material and the study was approved by the Institutional Review Board of the Changhua Christian Hospital (No. Y-108-0188).

\section{Author contributions}

Hsu-Heng Yen: Designing the work; the acquisition, analysis and interpretation of the data and revising draft copies. E-mail: blaneyen@gmail.com; 91646@cch.org.tw

Shu-Hui Chen: analysis and interpretation of the data, plus drafting the work. Contributed equally to Dr. Hsu-Heng Yen. E-mail: 6484@cch.org.tw 
Huei-Wen Lai: interpretation of the data and revising draft copies. E-mail: 84643@cch.org.tw

Hui-Lan Chang: interpretation of the data and revising draft copies. E-mail: 162418@cch.org.tw

Yu-Chun Hsu: Interpretation of the data and revising draft copies. Contributed equally to Dr. Yen. E-mail: 77149 @cch.org.tw

Fu-Yuan Siao: interpretation of the data, plus revising draft copies. E-mail: 57385@cch.org.tw

\section{Tables}

Table 1. Type of scope and scope contamination rate.

\begin{tabular}{|c|c|c|c|c|c|c|}
\hline $\begin{array}{c}\text { Type of } \\
\text { scope }\end{array}$ & $\begin{array}{l}\text { Number } \\
\text { of } \\
\text { scopes }\end{array}$ & $\begin{array}{c}\text { Age of } \\
\text { scope } \\
\text { (years; } \\
\text { mean } \pm \text { SD) }\end{array}$ & $\begin{array}{c}\text { Mean } \\
\text { monthly } \\
\text { usage } \\
\text { (number of } \\
\text { times; } \\
\text { mean } \pm \text { SD) }\end{array}$ & $\begin{array}{l}\text { Number } \\
\text { of } \\
\text { sampling }\end{array}$ & $\begin{array}{c}\text { Number } \\
\text { of } \\
\text { positive } \\
\text { cultures }\end{array}$ & $\begin{array}{c}\text { Scope } \\
\text { contamination } \\
\text { rate }(\%)\end{array}$ \\
\hline EGD & 16 & $4.5 \pm 2.11$ & $45.54 \pm 22.69$ & 765 & 15 & 2 \\
\hline Colon & 18 & 5.13 .03 & $27.96 \pm 17.02$ & 730 & 14 & 1.9 \\
\hline ERCP & 8 & $5.6 \pm 2.58$ & $15.12 \pm 7.92$ & 379 & 3 & 0.8 \\
\hline EUS & 1 & $2.5 \pm 1.13$ & $9.39 \pm 3.97$ & 46 & 2 & 4.3 \\
\hline $\begin{array}{c}\text { Balloon } \\
\text { endoscope }\end{array}$ & 1 & $1 \pm 0$ & $3.18 \pm 2.09$ & 11 & 1 & 9.1 \\
\hline
\end{tabular}

EGD, esophagogastroduodenoscopy; ERCP, endoscopic retrograde cholangiopancreatography; EUS, endoscopic ultrasound

Table 2. Scope culture and scope contamination rate by sampling year. 


\begin{tabular}{|c|c|c|c|}
\hline Year & $\begin{array}{l}\text { Number of } \\
\text { sampling cultures }\end{array}$ & Number of & Scope contamination rate (\%) \\
\hline 2014 & 316 & 9 & 2.8 \\
\hline 2015 & 318 & 2 & 0.6 \\
\hline 2016 & 416 & 3 & 0.7 \\
\hline 2017 & 415 & 3 & 0.7 \\
\hline 2018 & 466 & 18 & $3.9 *$ \\
\hline
\end{tabular}

* $P=0.0003$ compared with year 2014

Table 3. Scope contamination rate by scope age.

\begin{tabular}{|c|c|c|c|}
\hline Age of endoscope & Number of & Number of & Scope contamination rate (\%) \\
& sampling cultures & positive cultures & 0 \\
\hline 0 & 3 & 0 & 1.7 \\
\hline 1 & 233 & 4 & 0.9 \\
\hline 2 & 216 & 2 & 3.5 \\
\hline 3 & 230 & 8 & 2.8 \\
\hline 4 & 212 & 6 & 0.4 \\
\hline 5 & 246 & 1 & 1.9 \\
\hline 6 & 207 & 4 & 0.5 \\
\hline 7 & 215 & 4 & 3.1 \\
\hline 8 & 193 & 1 & 1.9 \\
\hline 9 & 97 & 3 & 4.0 \\
\hline 10 & 54 & 1 & 1 \\
\hline 11 & 25 & & \\
\hline
\end{tabular}


Table 4. Type of scope and microbiology culture results.

\begin{tabular}{|l|l|l|l|l|l|c|}
\hline Type of scope & EGD & Colon & ERCP & EUS & Balloon & Total \\
\hline Bacillus spp. & & 1 & 1 & & & 2 \\
\hline Corynebacterium spp. & & & & 1 & & 1 \\
\hline Acinetobacter baumannii & & 1 & & & & 1 \\
\hline Alcaligenes faecalis & & 1 & & & & 1 \\
\hline Candida spp. & 4 & 1 & & & & 5 \\
\hline Enterococcus spp. & 1 & & & & & 1 \\
\hline Klebsiella pneumoniae & 5 & 4 & 2 & 1 & 1 & 13 \\
\hline Pseudomonas aeruginosa & 5 & 6 & & & & 11 \\
\hline
\end{tabular}

EGD, esophagogastroduodenoscopy; ERCP, endoscopic retrograde cholangiopancreatography; EUS, endoscopic ultrasound

Table 5. Scope contamination from 2014 to 2018. 


\begin{tabular}{|c|c|c|c|c|c|c|}
\hline $\begin{array}{l}\text { Type } \\
\text { of } \\
\text { scope }\end{array}$ & Year & $\mathrm{CFU} / \mathrm{mL}$ & Bacteria & $\begin{array}{c}\text { Monthly } \\
\text { scope usage } \\
\text { (times) }\end{array}$ & $\begin{array}{l}\text { Cause of } \\
\text { scope } \\
\text { contamination }\end{array}$ & $\begin{array}{l}\text { Need for } \\
\text { Subsequent EO }\end{array}$ \\
\hline EGD & 2014 & 12 & $\begin{array}{l}\text { Klebsiella } \\
\text { pneumoniae }\end{array}$ & 70 & Human error & No \\
\hline Colon & 2014 & 10 & $\begin{array}{l}\text { Pseudomonas } \\
\text { aeruginosa }\end{array}$ & 29 & Human error & No \\
\hline EGD & 2014 & 80 & $\begin{array}{l}\text { Pseudomonas } \\
\text { aeruginosa }\end{array}$ & 10 & Human error & No \\
\hline Colon & 2014 & 40 & $\begin{array}{l}\text { Pseudomonas } \\
\text { aeruginosa }\end{array}$ & 22 & Human error & No \\
\hline Colon & 2014 & 40 & $\begin{array}{l}\text { Pseudomonas } \\
\text { aeruginosa }\end{array}$ & 65 & Human error & No \\
\hline Colon & 2014 & 10 & $\begin{array}{l}\text { Alcaligenes } \\
\text { faecalis }\end{array}$ & 15 & Human error & No \\
\hline Colon & 2014 & 20 & $\begin{array}{l}\text { Pseudomonas } \\
\text { aeruginosa }\end{array}$ & 37 & Human error & Pass after EO \\
\hline Colon & 2014 & 10 & $\begin{array}{l}\text { Pseudomonas } \\
\text { aeruginosa }\end{array}$ & 61 & $\begin{array}{l}\text { Scope } \\
\text { breakdown }\end{array}$ & $\begin{array}{l}\text { Failed after EO, } \\
\text { change scope } \\
\text { channel }\end{array}$ \\
\hline Colon & 2015 & 20 & $\begin{array}{l}\text { Klebsiella } \\
\text { pneumoniae }\end{array}$ & 52 & Human error & No \\
\hline EGD & 2015 & 6 & $\begin{array}{l}\text { Klebsiella } \\
\text { pneumoniae }\end{array}$ & 62 & Human error & No \\
\hline EGD & 2017 & 20 & $\begin{array}{l}\text { Klebsiella } \\
\text { pneumoniae }\end{array}$ & 9 & Human error & No \\
\hline Colon & 2017 & 100 & $\begin{array}{l}\text { Klebsiella } \\
\text { pneumoniae }\end{array}$ & 4 & Break of AER & No \\
\hline EGD & 2016 & 2 & $\begin{array}{l}\text { Pseudomonas } \\
\text { eruginosa }\end{array}$ & 43 & Human error & No \\
\hline Colon & 2016 & 200 & $\begin{array}{l}\text { Klebsiella } \\
\text { pneumoniae }\end{array}$ & 41 & Human error & No \\
\hline Colon & 2016 & 10 & $\begin{array}{l}\text { Acinetobacter } \\
\text { baumannii }\end{array}$ & 2 & Human error & No \\
\hline EGD & 2018 & 50 & $\begin{array}{l}\text { Pseudomonas } \\
\text { aeruginosa }\end{array}$ & 17 & $\begin{array}{l}\text { Break of AER } \\
\text { connector }\end{array}$ & No \\
\hline EGD & 2018 & 200 & $\begin{array}{l}\text { Klebsiella } \\
\text { pneumoniae }\end{array}$ & 23 & $\begin{array}{l}\text { Break of AER } \\
\text { connector }\end{array}$ & No \\
\hline EGD & 2018 & 80 & $\begin{array}{l}\text { Enterococcus } \\
\text { spp. }\end{array}$ & 19 & $\begin{array}{l}\text { Break of AER } \\
\text { connector }\end{array}$ & No \\
\hline EGD & 2018 & 10 & $\begin{array}{l}\text { Klebsiella } \\
\text { pneumoniae }\end{array}$ & 19 & Human error & No \\
\hline DBE & 2018 & 15 & $\begin{array}{l}\text { Klebsiella } \\
\text { pneumoniae }\end{array}$ & 3 & Human error & No \\
\hline EUS & 2018 & 50 & $\begin{array}{l}\text { Klebsiella } \\
\text { pneumoniae }\end{array}$ & 11 & Human error & No \\
\hline
\end{tabular}




\begin{tabular}{|c|c|c|c|c|c|c|}
\hline ERCP & 2018 & 80 & pneumoniae & 9 & Human error & $\begin{array}{l}\text { Pass after } \\
\text { ethylene oxide } \\
\text { disinfection }\end{array}$ \\
\hline Colon & 2018 & 5 & $\begin{array}{l}\text { Klebsiella } \\
\text { pneumoniae }\end{array}$ & 7 & Human error & No \\
\hline EGD & 2018 & 1 & Candida spp. & 59 & $\begin{array}{l}\text { Storage } \\
\text { cabinet } \\
\text { damage }\end{array}$ & No \\
\hline EGD & 2018 & 5 & Candida spp. & 61 & $\begin{array}{l}\text { Storage } \\
\text { cabinet } \\
\text { damage }\end{array}$ & No \\
\hline EGD & 2018 & 120 & Candida spp. & 58 & $\begin{array}{l}\text { Storage } \\
\text { cabinet } \\
\text { damage }\end{array}$ & No \\
\hline EGD & 2018 & 25 & Candida spp. & 52 & $\begin{array}{l}\text { Storage } \\
\text { cabinet } \\
\text { damage }\end{array}$ & No \\
\hline Colon & 2018 & 5 & Candida spp. & 14 & $\begin{array}{l}\text { Storage } \\
\text { cabinet } \\
\text { damage }\end{array}$ & No \\
\hline EGD & 2018 & 10 & $\begin{array}{l}\text { Pseudomonas } \\
\text { aeruginosa }\end{array}$ & 57 & Human error & No \\
\hline ERCP & 2018 & 2 & $\begin{array}{l}\text { Klebsiella } \\
\text { pneumoniae }\end{array}$ & 2 & Human error & No \\
\hline Colon & 2018 & 5 & $\begin{array}{l}\text { Pseudomonas } \\
\text { aeruginosa }\end{array}$ & 8 & Human error & No \\
\hline EGD & 2018 & 15 & $\begin{array}{l}\text { Pseudomonas } \\
\text { aeruginosa }\end{array}$ & 47 & Human error & No \\
\hline
\end{tabular}

CFU, colony-forming units; DBE, double balloon enteroscopy; EGD, esophagogastroduodenoscopy; ERCP, endoscopic retrograde cholangiopancreatography; EUS, endoscopic ultrasound

Table 6. Summary of current guideline recommendation about the frequency of microbiology surveillance of endoscope unit. 


\begin{tabular}{|c|c|c|}
\hline $\begin{array}{c}\text { Year of } \\
\text { Publication }\end{array}$ & Society Guidelines & Frequency of Microbiology Surveillance \\
\hline 2007 & ESGE-ESGENA[7] & $\begin{array}{l}\text { The frequency of microbiological surveillance and } \\
\text { recommended test procedures differs across } \\
\text { Europe. Monthly interval (Denmark, Monaco), 3- } \\
\text { monthly interval (Croatia, Germany, Spain, Sweden, } \\
\text { Switzerland ), yearly-interval (Austria, France), and } \\
\text { UK ( no tests of endoscopes). }\end{array}$ \\
\hline 2016 & $\begin{array}{l}\text { Multisociety } \\
\text { guideline on } \\
\text { reprocessing } \\
\text { flexible GI } \\
\text { endoscopes (USA) } \\
\text { [2] }\end{array}$ & $\begin{array}{l}\text { Microbiologic testing of endoscopes after } \\
\text { reprocessing, during storage, or before use, has not } \\
\text { been advised in current U.S. standard }\end{array}$ \\
\hline 2017 & $\begin{array}{c}\text { Gastroenterological } \\
\text { Society of Australia } \\
\text { [38] }\end{array}$ & $\begin{array}{c}\text { Surveillance frequency depends on types of } \\
\text { endoscopes. Monthly interval (ERCP and EUS } \\
\text { scope), and 3- monthly ( other gastrointestinal } \\
\text { scopes ) }\end{array}$ \\
\hline 2017 & $\begin{array}{l}\text { World Endoscopy } \\
\text { Organization [10] }\end{array}$ & $\begin{array}{c}\text { Endoscopes should be randomly tested at routine } \\
\text { intervals. Regular interval (Taiwan), quarterly } \\
\text { (China), every } 6 \text { months ( Indonesia ), or institution } \\
\text { specific (India) }\end{array}$ \\
\hline
\end{tabular}

\section{References}

1. Beilenhoff U, Neumann CS, Rey JF, Biering H, Blum R, Cimbro M, Kampf B, Rogers M, Schmidt V, Committee EG et al: ESGE-ESGENA Guideline: cleaning and disinfection in gastrointestinal endoscopy. Endoscopy 2008, 40(11):939-957.

2. Reprocessing Guideline Task F, Petersen BT, Cohen J, Hambrick RD, 3rd, Buttar N, Greenwald DA, Buscaglia JM, Collins J, Eisen G: Multisociety guideline on reprocessing flexible GI endoscopes: 2016 update. Gastrointest Endosc 2017, 85(2):282-294 e281.

3. Muscarella LF: Risk of transmission of carbapenem-resistant Enterobacteriaceae and related "superbugs" during gastrointestinal endoscopy. World J Gastrointest Endosc 2014, 6(10):457-474.

4. Rubin ZA, Kim S, Thaker AM, Muthusamy VR: Safely reprocessing duodenoscopes: current evidence and future directions. Lancet Gastroenterol Hepatol 2018, 3(7):499-508.

5. Rauwers AW, Voor In 't Holt AF, Buijs JG, de Groot W, Hansen BE, Bruno MJ, Vos MC: High prevalence rate of digestive tract bacteria in duodenoscopes: a nationwide study. Gut 2018, 67(9):1637-1645.

6. Paula H, Tribl B, Presterl E, Diab-El Schahawi M: Prospective microbiologic evaluation of the forceps elevator in closed-channel duodenoscopes after reprocessing. Am J Infect Control 2017, 45(2):121125. 
7. Beilenhoff U, Neumann CS, Rey JF, Biering H, Blum R, Schmidt V, Committee EG: ESGE-ESGENA guideline for quality assurance in reprocessing: microbiological surveillance testing in endoscopy. Endoscopy 2007, 39(2):175-181.

8. Ross AS, Baliga C, Verma P, Duchin J, Gluck M: A quarantine process for the resolution of duodenoscope-associated transmission of multidrug-resistant Escherichia coli. Gastrointest Endosc 2015, 82(3):477-483.

9. Devereaux BM, Athan E, Brown RR, Greig SM, Jones DM, Bailey FK, Wallis DJ, Singh R: Australian infection control in endoscopy consensus statements on carbapenemase-producing Enterobacteriaceae. J Gastroenterol Hepatol 2019, 34(4):650-658.

10. Murdani A, Kumar A, Chiu HM, Goh KL, Jang BI, Khor CJ, Lau J, Mostafa I, Ramchandani M, Ratanalert $S$ et al: WEO position statement on hygiene in digestive endoscopy: Focus on endoscopy units in Asia and the Middle East. Dig Endosc 2017, 29(1):3-15.

11. Yen H, Chen S, Huang M, Lin L: Use and Management of High-level Disinfection in an Endoscopy Center. Infection Control Journal 2012, 22(4):163-169.

12. Muscarella LF: Use of ethylene-oxide gas sterilisation to terminate multidrug-resistant bacterial outbreaks linked to duodenoscopes. BMJ Open Gastroentero/ 2019, 6(1):e000282.

13. Armellino D, Cifu K, Wallace M, Johnson S, DiCapua J, Dowling O, Jacobs M, Browning S: Implementation of remote video auditing with feedback and compliance for manual-cleaning protocols of endoscopic retrograde cholangiopancreatography endoscopes. Am J Infect Control 2018, 46(5):594-596.

14. Saliou P, Le Bars H, Payan C, Narbonne V, Cholet F, Jezequel J, Scotet V, Robaszkiewicz M, Cornec D, Hery-Arnaud $\mathrm{G}$ et al: Measures to improve microbial quality surveillance of gastrointestinal endoscopes. Endoscopy 2016, 48(8):704-710.

15. Bruns MA, Gibbs ER: Multidepartmental Response to a Duodenoscope Used on a CRE Patient: A Case Study. Gastroenterol Nurs 2017, 40(1):56-62.

16. Smith ZL, Oh YS, Saeian K, Edmiston CE, Jr., Khan AH, Massey BT, Dua KS: Transmission of carbapenem-resistant Enterobacteriaceae during ERCP: time to revisit the current reprocessing guidelines. Gastrointest Endosc 2015, 81(4):1041-1045.

17. Moses FM, Lee J: Surveillance cultures to monitor quality of gastrointestinal endoscope reprocessing. Am J Gastroenterol 2003, 98(1):77-81.

18. Chiu KW, Fong TV, Wu KL, Chiu YC, Chou YP, Kuo CM, Chuah SK, Kuo CH, Chiou SS, ChangChien CS: Surveillance culture of endoscope to monitor the quality of high-level disinfection of gastrointestinal reprocessing. Hepatogastroenterology 2010, 57(99-100):531-534.

19. Sethi S, Huang RJ, Barakat MT, Banaei N, Friedland S, Banerjee S: Adenosine triphosphate bioluminescence for bacteriologic surveillance and reprocessing strategies for minimizing risk of infection transmission by duodenoscopes. Gastrointest Endosc 2017, 85(6):1180-1187 e1181.

20. Chang WK, Liu TC, Liu TL, Peng CL, Wang HP: Enhanced manual cleaning efficacy of duodenoscope in endoscopy units: Results of a multicenter comprehensive quality control program. Am J Infect 
Control 2019.

21. Shin SP, Kim WH: Recent Update on Microbiological Monitoring of Gastrointestinal Endoscopes after High-Level Disinfection. Clin Endosc 2015, 48(5):369-373.

22. Cattoir L, Vanzieleghem T, Florin L, Helleputte T, De Vos M, Verhasselt B, Boelens J, Leroux-Roels I: Surveillance of Endoscopes: Comparison of Different Sampling Techniques. Infect Control Hosp Epidemiol 2017, 38(9):1062-1069.

23. Lu LS, Wu KL, Chiu YC, Lin MT, Hu TH, Chiu KW: Swab culture monitoring of automated endoscope reprocessors after high-level disinfection. World J Gastroentero/ 2012, 18(14):1660-1663.

24. Grace Thornhill MD: Endoscope-Associated Infections: A Microbiologist's perspective on current technologies. Techniques in Gastrointestinal Endoscopy 2019.

25. Chiu KW, Tsai MC, Wu KL, Chiu YC, Lin MT, Hu TH: Surveillance cultures of samples obtained from biopsy channels and automated endoscope reprocessors after high-level disinfection of gastrointestinal endoscopes. BMC Gastroenterol 2012, 12:120.

26. Cho YK, Moon JS, Han DS, Lee YC, Kim Y, Park BY, Chung IK, Kim JO, Im JP, Cha JM et al: Feedback Survey of the Effect, Burden, and Cost of the National Endoscopic Quality Assessment Program during the Past 5 Years in Korea. Clin Endosc 2016, 49(6):542-547.

27. Higa JT, Choe J, Tombs D, Gluck M, Ross AS: Optimizing duodenoscope reprocessing: rigorous assessment of a culture and quarantine protocol. Gastrointest Endosc 2018, 88(2):223-229.

28. Rutala WA, Weber DJ: Reprocessing endoscopes: United States perspective. J Hosp Infect 2004, 56 Suppl 2:S27-39.

29. Soares JB, Goncalves R, Banhudo A, Pedrosa J: Reprocessing practice in digestive endoscopy units of district hospitals: results of a Portuguese National Survey. Eur J Gastroenterol Hepato/ 2011, 23(11):1064-1068.

30. Jolly JD, Hildebrand EA, Branaghan RJ, Garland TB, Epstein D, Babcock-Parziale J, Brown V: Patient safety and reprocessing: A usability test of the endoscope reprocessing procedure. Human Factors and Ergonomics in Manufacturing \& Service Industries 2012, 22(1):39-51.

31. Hildebrand EA, Branaghan RJ, Neuman BL, Jolly J, Garland TB, Taggart M, Epstein DR, BabcockParziale J, Brown V: An Expert Perspective of Errors in Endoscope Reprocessing. Proceedings of the Human Factors and Ergonomics Society Annual Meeting 2011, 55(1):748-752.

32. Hildebrand EA, Branaghan RJ, Wu Q, Jolly J, Garland TB, Taggart M, Nguyen MA, Epstein DR, Babcock-Parziale J, Brown V: Exploring Human Factors in Endoscope Reprocessing. Proceedings of the Human Factors and Ergonomics Society Annual Meeting 2010, 54(12):894-898.

33. Seelen MT, Friend TH, Levine WC: Optimizing Endoscope Reprocessing Resources Via Process Flow Queuing Analysis. J Med Syst 2018, 42(6):111.

34. Park JB, Yang JN, Lim YJ, Koo JS, Jang JY, Park SH, Hong SJ, Kim SW, Chun HJ, Disinfection Management Committee of the Korean Society of Gastrointestinal E: Survey of endoscope reprocessing in Korea. Clin Endosc 2015, 48(1):39-47. 
35. Sinocruz JQ, Hildebrand EA, Neuman BL, Branaghan RJ: Human Factors Implications for Standard Operating Procedure Development and Usability in Reprocessing Safety. Proceedings of the Human Factors and Ergonomics Society Annual Meeting 2011, 55(1):803-807.

36. Rauwers AW, Kwakman JA, Vos MC, Bruno MJ: Endoscope-associated infections: A brief summary of the current state and views toward the future. Techniques in Gastrointestinal Endoscopy 2019.

37. Ji XY, Ning PY, Fei CN, Liu J, Liu H, Song J: The importance of sampling technique and rinse water for assessing flexible gastrointestinal endoscope reprocessing: A 3-year study covering 59 centers. Am J Infect Control 2019.

38. CALHN S, NALHN, CHSALHN, WCHN: Clinical Guideline Microbiological Testing of Endoscopes Clinical Guideline. 2017.

\section{Figures}

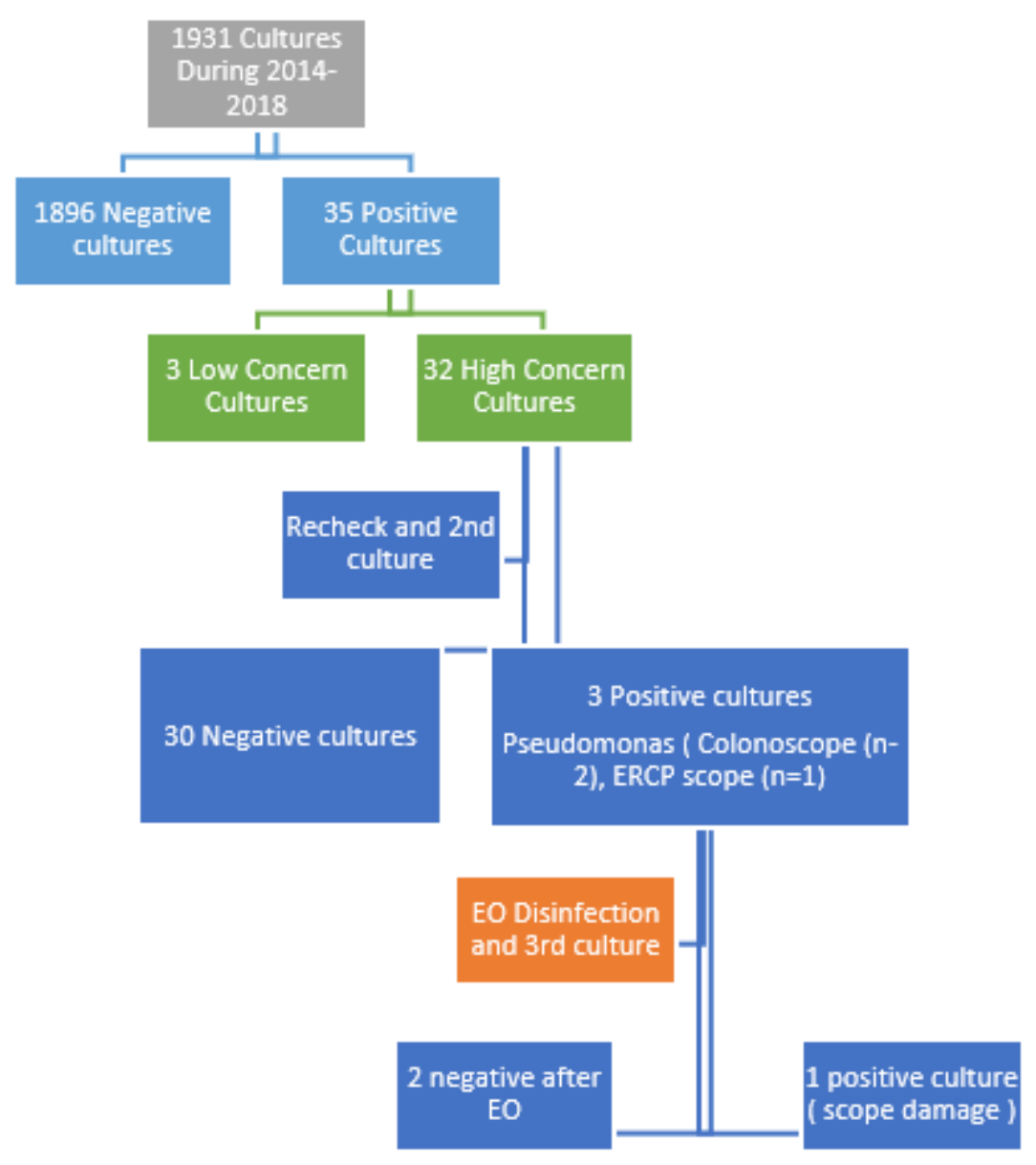

Figure 1

Endoscopy unit culture results from 2014 to 2018. 